\title{
Evaluation of ocean crustal Sites 1256 and 504 for long-term $\mathrm{CO}_{2}$ sequestration
}

\author{
Angela L. Slagle ${ }^{1}$ and David S. Goldberg ${ }^{1}$ \\ Received 21 June 2011; accepted 14 July 2011; published 20 August 2011.
}

[1] Geologic storage of $\mathrm{CO}_{2}$ in ocean basalt reservoirs is a potentially long-term solution to offset anthropogenic greenhouse gas emissions. Prior drilling at Deep Sea Drilling Project (DSDP)/Ocean Drilling Program (ODP)/ Integrated Ocean Drilling Program (IODP) Sites 1256 and 504 provides evidence that the extrusive ocean crust has sufficient porosity and permeability to enable storage of large volumes of $\mathrm{CO}_{2}$. Six intervals are identified as potential reservoirs in the shallow crust at Sites 1256 and 504 , with new and reprocessed estimates of porosity from electrical resistivity logs ranging from $6 \%$ to $14 \%$ and permeability from $\sim 10^{-14}$ to $10^{-15} \mathrm{~m}^{2}$. Calculations using specific reservoir thickness and porosity estimates suggest that even the smallest reservoir could provide storage capacity for decades of global anthropogenic carbon emissions. In situ hydrologic experiments and pilot injection studies are needed to confirm high permeability and porosity estimates at Sites 1256 and 504, as well as the potential for $\mathrm{CO}_{2}$ injection and retention in these basalt reservoirs. Citation: Slagle, A. L., and D. S. Goldberg (2011), Evaluation of ocean crustal Sites 1256 and 504 for long-term $\mathrm{CO}_{2}$ sequestration, Geophys. Res. Lett., 38, L16307, doi:10.1029/ 2011 GL048613.

\section{Introduction}

[2] With continued rise in atmospheric $\mathrm{CO}_{2}$ from anthropogenic input and increased awareness that rising $\mathrm{CO}_{2}$ may drive rapid climate change, interest in geologic sequestration has been growing [Metz et al., 2005]. Mafic and ultramafic reservoirs, and deep-sea basalt in particular, have been proposed as advantageous storage options for anthropogenic carbon [Goldberg et al., 2008; Oelkers et al., 2008; Matter and Kelemen, 2009]. In the ocean crust, pillow lavas, breccias, and flows form large permeable reservoirs capped by seafloor sediments [Fisher, 1998] and seafloor weathering reactions between basalt, $\mathrm{CO}_{2}$, and seawater produce carbonate minerals over time [e.g., Alt, 1995]. The potential for carbon sequestration in ocean crust is based on the chemical reactivity of basalt with injected $\mathrm{CO}_{2}$ to form stable carbonates in an analog of the natural weathering process, which Takahashi et al. [2000] suggest may occur at a rapid rate. In a study of drill core data quantifying the carbon content of altered ocean crust from multiple ocean basins, Gillis and Coogan [2011] determine that higher fluid temperatures in the crust have increased reaction rates, freeing more basaltic $\mathrm{Ca}$, and enhancing carbonate miner-

\footnotetext{
${ }^{1}$ Lamont-Doherty Earth Observatory, Earth Institute at Columbia University, Palisades, New York, USA.

Copyright 2011 by the American Geophysical Union. 0094-8276/11/2011GL048613
}

alization. Shilobreeva et al. [2011] analyze samples of altered crust from Ocean Drilling Program (ODP)/Integrated Ocean Drilling Program (IODP) Site 1256 and identify carbon contributions from both magmatic $\mathrm{CO}_{2}$ and seawater bicarbonates in the volcanic section of crust.

[3] Mineral carbonation acts as a long-term carbon trap in ocean basalt reservoirs, but also provides the advantages of short-term trapping mechanisms, including: (i) thick sediments that form a low-permeability barrier impeding vertical fluid flow [e.g., Alt and Teagle, 2003]; (ii) the formation of $\mathrm{CO}_{2}$ gas hydrate, which is denser and less soluble than liquid $\mathrm{CO}_{2}$ in seawater $<2^{\circ} \mathrm{C}$ [Brewer et al., 1999]; and (iii) gravitational trapping at water depths $>2700 \mathrm{~m}$, where injected $\mathrm{CO}_{2}$ is denser than seawater [House et al., 2006]. In a global assessment, Goldberg and Slagle [2009] use broad parameters (i.e., sediment thickness and water depth) along with crustal age as a proxy for porosity to calculate potential carbon storage volumes in basalt along the flanks of eleven mid-ocean ridges and seven aseismic ridges, including the Cocos-Nazca Spreading system in the Pacific. The total carbon storage estimated for these reservoirs ranges from 2.3-11.5 Tt-C along mid-ocean ridges to 5.9-29.6 $\mathrm{Tt}-\mathrm{C}$ along aseismic ridges. For greater certainty and precision in storage potential at any of these locations, site-specific characterization of ocean crust is required.

[4] In this study, we present new calculations of porosity from electrical resistivity and sonic logging data for two drill sites in the shallow ocean crust along the flanks of the Cocos-Nazca Spreading Ridge in the eastern equatorial Pacific. These sites - 1256 and 504 - were drilled by the Deep Sea Drilling Project (DSDP), ODP and IODP and are the deepest and best-characterized continuous sections through intact ocean crust. We use our porosity estimates in conjunction with natural gamma ray radioactivity log data and previous in situ permeability estimates from Site 504 to identify and evaluate specific potential reservoirs for longterm $\mathrm{CO}_{2}$ sequestration at both sites. This approach provides new estimates of the carbon storage potential in the equatorial Pacific and also offers insight into the shallow crustal reservoirs in other potential storage locations.

\section{Data and Methods}

\subsection{Sites 1256 and $\mathbf{5 0 4}$}

[5] Sites 1256 and 504 provide a detailed picture of the morphology, structure, geochemistry, and physical properties of ocean crust [Cann et al., 1983; Alt et al., 1993; Wilson et al., 2003; Teagle et al., 2006; Wilson et al., 2006]. Three expeditions to Site 1256 drilled $1257 \mathrm{~m}$ into basement, penetrating 15 Ma crust formed on the East Pacific Rise during a period of superfast seafloor spreading. This site lies on the Cocos Plate in a region with no seismic 


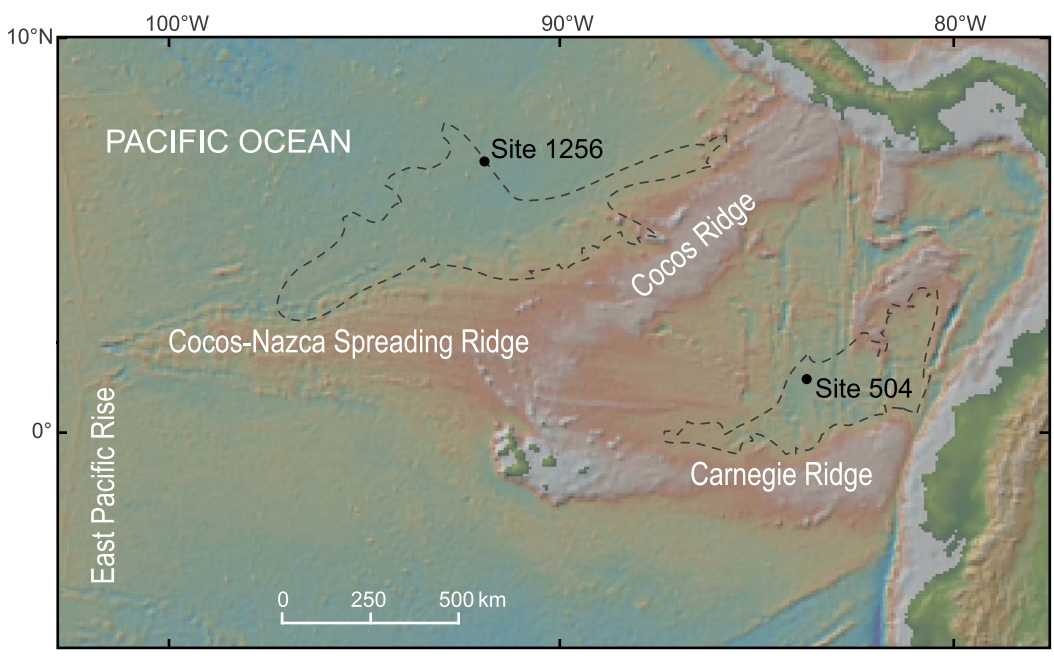

Figure 1. Location of Sites 1256 and 504 with seafloor bathymetry of the Cocos-Nazca Spreading system in the eastern equatorial Pacific. Dashed outlines show regions of suitable $\mathrm{CO}_{2}$ aquifer assessment following the method of Goldberg and Slagle [2009].

indication of shallow faulting, $\sim 1250 \mathrm{~km}$ from the CocosPacific-Nazca triple junction (Figure 1). The drilled sequence comprises $250 \mathrm{~m}$ of sediment over primarily extrusive and intrusive basalt. Seven expeditions to Site 504 penetrated $1836 \mathrm{~m}$ into basement in $6.9 \mathrm{Ma}$ crust formed at the Costa Rica Rift, the eastern segment of the Cocos-Nazca Spreading Ridge. This site is located $\sim 200 \mathrm{~km}$ south of the ridge and penetrated $275 \mathrm{~m}$ of sediment over a thick section of extrusive basalt and into intrusive dikes. Water depth $(3460 \mathrm{~m})$ is similar to Site 1256 (3635 $\mathrm{m}$ water) and basement topography is relatively smooth at both sites. Basement relief north of Site 504 is rougher, dominated by east-west striking normal faults forming basement outcrops. There is no present evidence of active fluid circulation at Site 1256, but repeat observations at Site 504 provide evidence of active fluid flow that can only be explained by vigorous lateral flow in the shallow basement [e.g., Davis et al., 2004].

[6] Downhole logging data acquired during multiple expeditions were critical to characterizing the volcanic lithostratigraphy because core recovery was generally $\leq 50 \%$ at these sites. The cored extrusives at Site 1256 comprise sheet flows with minor pillows, and hyaloclastites, capped by a massive flow. Tominaga et al. [2009] provide a detailed volcanostratigraphy based on high-resolution resistivity images acquired during logging, distinguishing 26\% massive flows, $\sim 50 \%$ fractured lavas and breccias, and $\sim 2 \%$ pillows. The cored extrusive sequence at Site 504 comprises pillow basalts, flows, and breccias, overlying a transition zone and dike section. Pezard [1990] used lower-resolution resistivity $\log$ data and in situ permeability measurements to estimate that the volcanostratigraphy consists of $\sim 70 \%$ pillow basalts, $\sim 26 \%$ flows, and $\sim 4 \%$ dikes. The two logbased methods differ in that resistivity images investigate a much smaller volume of rock $\left(\sim \mathrm{cm}^{3}\right)$ than the resistivity log data $\left(\sim \mathrm{m}^{3}\right)$; however, both are based on resistivity measurements, provide continuous downhole data, and offer more greatly constrained interpretations of volcanostratigraphy than core-based methods alone.

\subsection{Porosity Estimates for Ocean Crust}

[7] We calculate porosity in these crustal sites using electrical resistivity and sonic velocity logs. For resistivitybased estimates, we use deep-reading resistivity logs, pore water resistivities calculated from measured salinity and temperature, and assume Archie coefficients $a=1$ and $m=2$ [e.g., Becker, 1985]. For velocity-based estimates, we use the time-average equation and reprocessed sonic logs [Guerin et al., 2008], assuming $V_{\text {fluid }}=1531 \mathrm{~m} / \mathrm{s}$, and $V_{\text {grain }}=7950$ and $7710 \mathrm{~m} / \mathrm{s}$, for Sites 1256 and 504, respectively. We calculate average $V_{\text {grain }}$ values based on core-based petrologic analyses on hand samples and thin sections from Wilson et al. [2003] and Alt et al. [1993].

[8] Calculated porosities are shown in Figures 2 and 3. Resistivity-based estimates are generally believed to be more reliable and correspond more closely with core-based measurements. Velocity-based estimates tend to overestimate porosity at both sites, which may result, in part, from the assumptions for $V_{\text {grain }}$ or time-averaged sonic propagation through the bulk rock.

\subsection{Basalt Alteration}

[9] Alteration of oceanic basalt occurs naturally through fluid-rock reactions as the crust ages, depositing clay, carbonate, and other minerals in open pore space and cracks [Staudigel et al., 1981; Alt, 1995]. Mineral formation may continue for millions of years before pore volume is filled by natural alteration processes [Jarrard et al., 2003].

[10] Natural gamma ray measurements, responding to radioactive elements, provide a reliable proxy for alteration by clays and other alteration minerals (e.g., celadonite) in the basalt crust [e.g., Broglia and Moos, 1988]. Gamma ray values above the background value ( 1-2 gAPI) correspond well with most intervals of altered basalt described at Sites 1256 and 504 (Figures 2 and 3). Volcanic rocks recovered at Site 1256 appear less altered than those at Site 504 [e.g., Wilson et al., 2003; Alt et al., 2010] and alteration is typically less advanced in massive flows, which act as natural barriers to fluid circulation [e.g., Cann et al., 1983]. Site 1256 has uniform background 


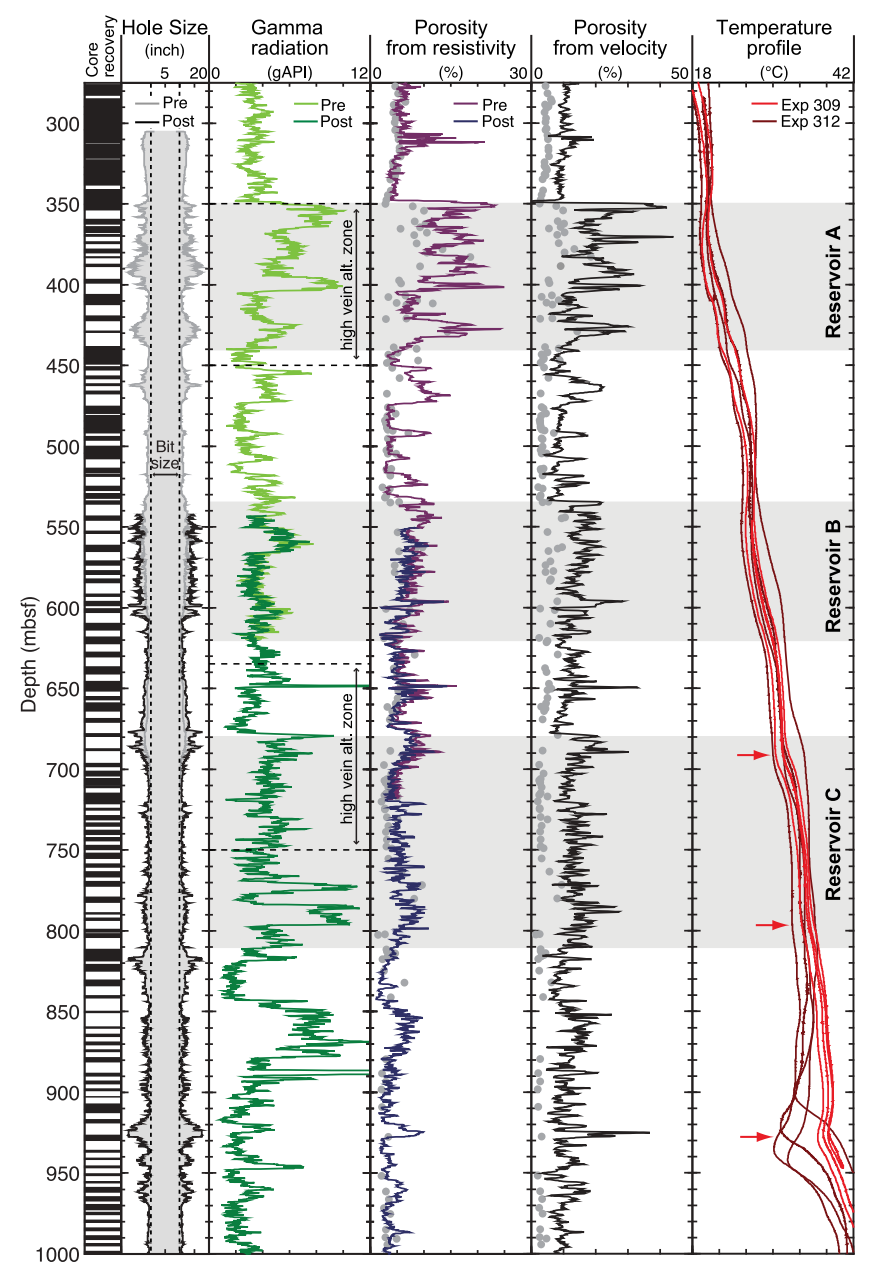

Figure 2. Logging data from the volcanic section at Site 1256. Pre- and post-drilling caliper and gamma ray logs were collected during IODP Expedition 309. Temperature logs were collected during IODP Expeditions 309 and 312. Resistivityand sonic-based porosity from this study. Dashed lines with gamma ray show core alteration zones [from Wilson et al., 2003]. Gray dots are IODP core porosity data. Red arrows show temperature perturbations. Gray shading shows potential reservoirs for carbon sequestration $(\mathrm{A}-\mathrm{C})$.

alteration, with saponite replacing olivine and interstitial glass and filling voids. Vein alteration is focused in two zones (Figure 2), with increased celadonite and Fe-oxyhydroxide veins typical of low-temperature alteration. Two lowtemperature alteration zones were documented in the volcanic section at Site 504 [Alt et al., 1985; Alt, 1995]. Basalts in the upper zone have increased $\mathrm{K}$ and voids are filled with $\mathrm{Fe}$-hydroxides, celadonite, and saponite, resulting from both oxidative and anoxic processes. The lower alteration zone is characterized by saponite and pyrite, formed under anoxic conditions.

\subsection{Permeability Estimates for Ocean Crust}

[11] The permeability of ocean crust is dominated by interconnected porosity, varies extensively with the presence of fractures, and cannot be simply determined from core measurements [Fisher, 1998]. In situ packer testing allows for large-scale permeability measurements in the crust. Previous packer experiments at Site 504 indicate permeability of $\sim 10^{-14}-10^{-13} \mathrm{~m}^{2}$ in the upper $\sim 100-200 \mathrm{~m}$ of the crust and $\leq 10^{-17} \mathrm{~m}^{2}$ below $\sim 550 \mathrm{~m}$ [Anderson et al., 1985].

[12] In situ permeability measurements have not been made to date at Site 1256. Anderson et al. [1985] suggest a relationship between resistivity-porosity and permeability in the shallow crust at Site 504. We approximate an empirical relationship between apparent porosity [Becker et al., 1982] and measured permeability [Anderson and Zoback, 1982; Anderson et al., 1985; Becker, 1989, 1996] for Sites 504 and 896:

$$
k=\left(2 \times 10^{-15} \mathrm{~m}^{2}\right) \varphi-4 \times 10^{-15} \mathrm{~m}^{2},
$$

where $k$ is permeability in $\mathrm{m}^{2}$ and $\varphi$ is porosity in \%. Similar linear relationships have been suggested for exploration environments [e.g., Doveton, 1994]. Owing to its similar lithostratigraphy and porosity, we also use this linear

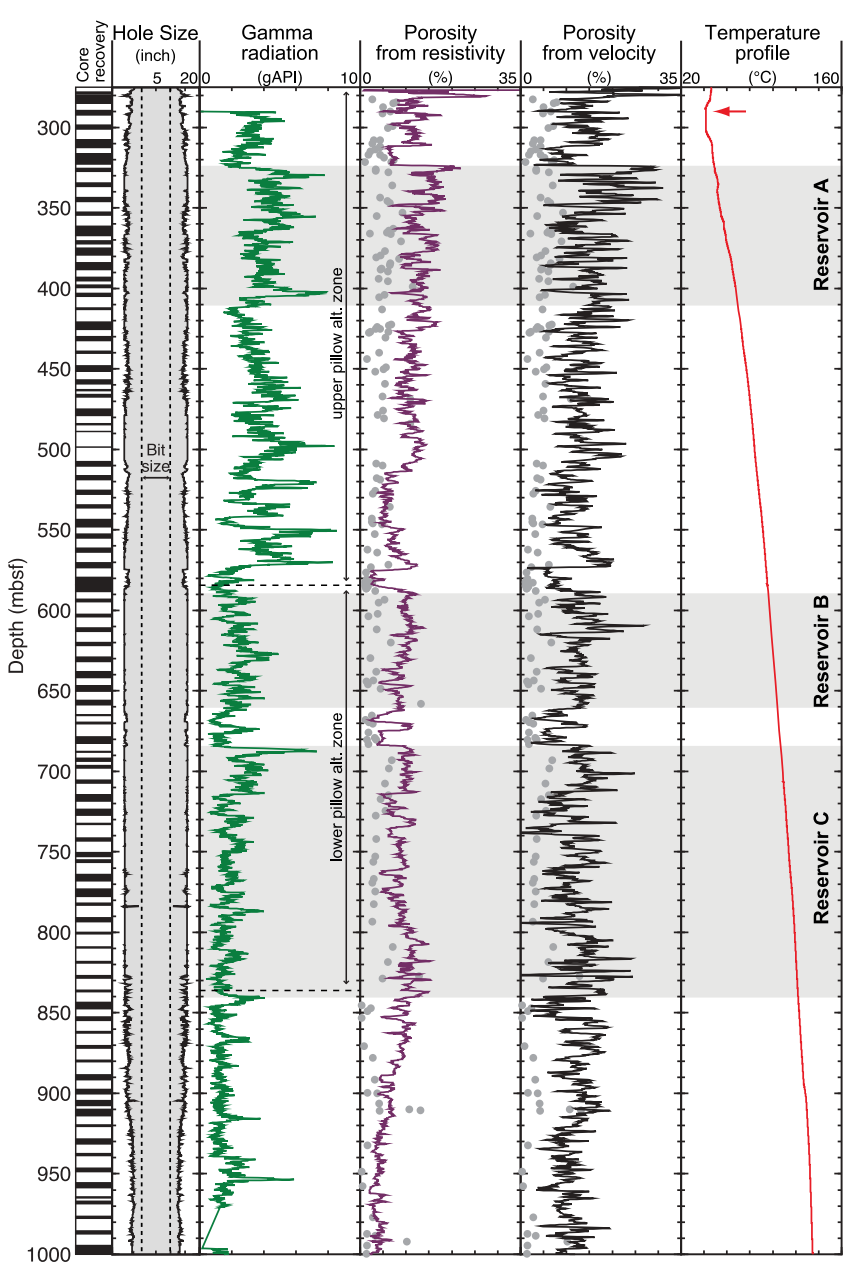

Figure 3. Logging data from the volcanic section at Site 504 . Caliper, gamma ray, and temperature logs were collected during ODP Leg 148. Resistivity- and sonic-based porosity from this study. Dashed lines with gamma ray show core alteration zones [from Alt et al., 1985]. Gray dots are ODP core porosity data. Red arrow shows temperature perturbation. Gray shading shows potential reservoirs for carbon sequestration $(\mathrm{A}-\mathrm{C})$. 
Table 1. Mean Reservoir Properties, Sites 1256 and 504

\begin{tabular}{lccccc}
\hline Site & Reservoir & $\begin{array}{c}\text { Depth } \\
(\mathrm{mbsf})\end{array}$ & $\begin{array}{c}\text { Resistivity } \\
\text { Porosity }(\%)\end{array}$ & $\begin{array}{c}\text { Permeability } \\
\left(\mathrm{m}^{2}\right)\end{array}$ & $\begin{array}{c}\text { Gamma } \\
\text { Ray } \\
(\mathrm{gAPI})\end{array}$ \\
\hline 1256 & A & $350-440$ & 13 & $2 \times 10^{-14 \mathrm{a}}$ & 5.6 \\
1256 & B & $535-620$ & 8 & $1 \times 10^{-14 \mathrm{a}}$ & 4.3 \\
1256 & C & $680-810$ & 6 & $8 \times 10^{-15 a}$ & 5.0 \\
504 & A & $325-410$ & 14 & $1 \times 10^{-14}-4 \times 10^{-14 b}$ & 4.3 \\
504 & B & $590-660$ & 9 & $1.4 \times 10^{-17 b}$ & 2.4 \\
504 & C & $685-840$ & 9 & $1.4 \times 10^{-17 b}$ & 2.0 \\
\hline
\end{tabular}

${ }^{a}$ Permeability based on a linear permeability-porosity relationship at Sites 504 and 896.

${ }^{\mathrm{b}}$ Permeability from packer experiments [Anderson and Zoback, 1982; Becker, 1996].

approximation to estimate bulk permeability from resistivityporosity data at Site 1256.

\section{Results}

[13] Based on downhole data from these sites we identify three potential reservoirs in the upper $1 \mathrm{~km}$ of the crust at Site 1256 (Figure 2, reservoirs A-C) and three at Site 504B (Figure 3, reservoirs A-C). Table 1 shows our evaluation of the physical properties of these reservoirs.

[14] All six reservoirs are overlain by massive flows which are expected to act as natural impermeable barriers and prevent upward fluid migration in the vicinity of the site. At Site 504, all three reservoirs A (325-410 mbsf), B (590-660 mbsf) and C (685-840 mbsf) are located in the extrusive section of pillow basalts. At Site 1256, the three reservoirs are located in more varying lithologies. Reservoir A (350-440 mbsf) is an interval of alternating fractured flows and altered breccias (high gamma ray values) in the shallowest part of the volcanic section. Reservoir B (535$620 \mathrm{mbsf}$ ) is dominated by fractured flows and Reservoir C (680-810 mbsf) corresponds to an interval of pillow lavas, altered breccias, and fractured flows.

[15] The shallowest " $A$ " reservoirs at both sites have the highest apparent porosity values (13-14\%) and the largest mean permeability estimates $\left(10^{-14}-10^{-15} \mathrm{~m}^{2}\right)$ compared to the deeper reservoir intervals. It is important to note, however, that the shallower intervals are also characterized by greater alteration (higher gamma ray values) and thus may or may not be similarly affected by water-rock reactions introduced by $\mathrm{CO}_{2}$ injection. A comparison of these six reservoirs is discussed below.

\section{Discussion}

[16] All six reservoirs identified at Sites 1256 and 504 are promising targets and may be suitable intervals for $\mathrm{CO}_{2}$ injection and sequestration. The relative importance of greater porosity and permeability in the " $\mathrm{A}$ " reservoirs given their greater volume of alteration material is unknown. Natural alteration processes may significantly reduce the effective porosity and permeability in these reservoirs, negating those advantages for injection. Alteration is significantly lower at Site 1256 than at Site 504 and, therefore, Site 1256 may offer fresher basalt surfaces for water-rock reactions after $\mathrm{CO}_{2}$ injection. The difference in natural alteration may be explained by higher average temperatures at Site 504 (Figures 2 and 3), which induce greater hydrothermal forcing and higher water/rock ratios, likely accelerating the crustal alteration process [Gillis and Coogan, 2011]. However, by the same process, higher fluid temperatures at Site 504 could lead to faster reaction kinetics with injected $\mathrm{CO}_{2}$, providing more rapid carbon mineralization.

[17] Assessing reservoir properties in the absence of direct measurements requires assumptions about physical properties based on empirical or other relationships. For example, the presence of alteration minerals in basalt may increase the bulk conductivity, and thus overestimate porosity using the Archie formulation [Pezard, 1990]. At Site 504, resistivityderived porosity is indeed higher than core measurements (Figure 3). At Site 1256, the estimated permeability in Reservoir $\mathrm{C}$ is lower than in $\mathrm{A}$ and $\mathrm{B}$, but the temperature $\log$ in $\mathrm{C}$ also shows the greatest departure from equilibrium temperature (Figure 2). This suggests that it was easily invaded by cold seawater during drilling and could have higher permeability than empirically predicted by equation (1). Reservoir $\mathrm{C}$, therefore, may be more suitable for injection. Direct and independent in situ measurements in these reservoirs is required to evaluate our assumptions and directly confirm their relative potential for $\mathrm{CO}_{2}$ sequestration.

[18] Using site-specific thickness and new estimations of porosity for potential reservoirs, we can compute carbon storage capacity for the shallow crust near Sites 1256 and 504. Following the method of Goldberg et al. [2008] and Goldberg and Slagle [2009], we establish bathymetric and sediment thickness constraints and avoid natural inflow/ outflow zones in critical regions around the two sites (see Figure 1). Assuming no significant leakage through conductive shallow faulting in these regions, we calculate $\sim 6,500 \mathrm{~km}^{3}$ of total potential pore volume for secure $\mathrm{CO}_{2}$ storage in the combined reservoirs near Site 1256 and $\sim 4,000 \mathrm{~km}^{3}$ near Site 504 . Each site offers multiple potential reservoirs in reasonable proximity to industrial ports. If liquefied $\mathrm{CO}_{2}$ is injected to completely fill even the smallest of these six reservoirs (Reservoir B, Site 504), it could hold a total of $\sim 210-280 \mathrm{Gt}$ of carbon. At the estimated global annual emission rate of $8.7 \pm 0.5 \mathrm{Gt} \mathrm{C} \mathrm{yr}^{-1}$ [Le Quéré et al., 2009], this reservoir alone could provide storage capacity for 24-32 years of anthropogenic $\mathrm{CO}_{2}$ emissions.

[19] Further in situ experimentation is required to test the new estimates of porosity, permeability, and carbon storage capacity. In situ hydrologic evaluations such as packer experiments, cross-hole tracer testing [e.g., Fisher et al., 2008], and subseafloor hydrogeologic observatories would all provide critical new data for this purpose. Paired holes, in particular, offer an opportunity for long-term in situ monitoring in one hole without interruption after injection in the other, an effective geometry to observe the fate of injected $\mathrm{CO}_{2}$ [e.g., Kharaka et al., 2006]. Along the Cocos-Nazca Spreading Ridge, a new companion hole would need to be drilled near Site 1256, but paired holes exist between Site 504 and nearby Site 896. Either apart from, or in conjunction with, future drilling activities at these sites, such experimentation in the ocean crust would confirm the potential for $\mathrm{CO}_{2}$ sequestration in these reservoirs and be used to predict similar properties at other oceanic ridge locations.

\section{Conclusions}

[20] Ocean basalt reservoirs offer vast potential storage space for long-term carbon sequestration. Based on drilling 
and logging data from ocean drilling Sites 1256 and 504 in the eastern equatorial Pacific, six reservoirs are identified in the shallow oceanic crust with high potential for the injection and storage of $\mathrm{CO}_{2}$. These reservoirs have high porosity and permeability and are capped by low permeability, massive lava flows. The shallowest reservoirs at both sites have the highest porosity $(13-14 \%)$ and estimated permeability $\left(10^{-14}-10^{-15} \mathrm{~m}^{2}\right)$, but also indications of greater natural alteration products compared to the deeper reservoirs. Carbon storage capacity calculations indicate $\sim 6,500 \mathrm{~km}^{3}$ and $\sim 4,000 \mathrm{~km}^{3}$ of total pore volume for injected $\mathrm{CO}_{2}$ storage in the combined reservoirs near Sites 1256 and 504, respectively. Even the smallest reservoir alone could provide storage capacity for decades of anthropogenic carbon emissions. All six reservoirs are promising candidates for potential sequestration reservoirs and warrant future hydrogeological experimentation and research.

[21] Acknowledgments. This research used samples and data provided by the Integrated Ocean Drilling Program (IODP; www.iodp.org). Discussions with G. Guerin and comments by A. Malinverno significantly improved this paper. LDEO contribution 7486.

[22] The Editor thanks an anonymous reviewer for their assistance in evaluating this paper.

\section{References}

Alt, J. C. (1995), Subseafloor processes in mid-ocean ridge hydrothermal systems, in Seafloor Hydrothermal Systems: Physical, Chemical, Biological and Geological Interactions, Geophys. Monogr. Ser., vol. 91, edited by S. E. Humphris et al., pp. 85-114, AGU, Washington, D. C.

Alt, J. C., and D. A. H. Teagle (2003), Hydrothermal alteration of upper oceanic crust formed at a fast spreading ridge: Mineral, chemical, and isotopic evidence from ODP Site 801, Chem. Geol., 201, 191-211, doi:10.1016/S0009-2541(03)00201-8.

Alt, J. C., C. Laverne, and K. Muehlenbachs (1985), Alteration of the upper oceanic crust: Mineralogy and processes in Deep Sea Drilling Project Hole 504B, Leg 83, Init. Rep. Deep Sea Drill. Project, 83, 217-247.

Alt, J. C., et al. (1993), Proceedings of the Ocean Drilling Program, Initial Reports, vol. 148, Ocean Drill. Program, College Station, Tex.

Alt, J. C., C. Laverne, R. M. Coggon, D. A. H. Teagle, N. R. Banerjee, S. Morgan, C. E. Smith-Duque, M. Harris, and L. Galli (2010), Subsurface structure of a submarine hydrothermal system in ocean crust formed at the East Pacific Rise, ODP/IODP Site 1256, Geochem. Geophys. Geosyst., 11, Q10010, doi:10.1029/2010GC003144.

Anderson, R. N., and M. D. Zoback (1982), Permeability, underpressures, and convection in the oceanic crust near the Costa Rica Rift, eastern equatorial Pacific, J. Geophys. Res., 87(B4), 2860-2868, doi:10.1029/ JB087iB04p02860.

Anderson, R. N., M. D. Zoback, S. H. Hickman, and R. L. Newmark (1985), Permeability versus depth in the upper oceanic crust: In situ measurements in DSDP Hole 504B, eastern equatorial Pacific, J. Geophys. Res., 90(B5), 3659-3669, doi:10.1029/JB090iB05p03659.

Becker, K. (1985), Large-scale electrical resistivity and bulk porosity of the oceanic crust, DSDP Hole 504B, Costa Rica Rift, Init. Rep. Deep Sea Drill Project, 83, 419-427.

Becker, K. (1989), Measurements of the permeability of the sheeted dikes in Hole 504B, ODP Leg 111, Proc. Ocean Drill. Program Sci. Results, $111,317-325$.

Becker, K. (1996), Permeability measurements in Hole 896A and implications for the lateral variability of upper crustal permeability at Sites 504 and 896, Proc. Ocean Drill. Program Sci. Results, 148, 353-363.

Becker, K., et al. (1982), In situ electrical resistivity and bulk porosity of the oceanic crust Costa Rica Rift, Nature, 300, 594-598, doi:10.1038/ $300594 \mathrm{a} 0$.

Brewer, P. G., et al. (1999), Direct experiments on the ocean disposal of fossil fuel $\mathrm{CO}_{2}$, Science, 284, 943-945, doi:10.1126/science.284.5416.943.

Broglia, C., and D. Moos (1988), In-situ structure and properties of 110-Ma crust from geophysical logs in DSDP Hole 418A, Proc. Ocean Drill. Program Sci. Results, 102, 29-47.
Cann, J. R., et al. (1983), Initial Reports of the Deep Sea Drilling Project, vol. 69, U.S. Govt. Print Office, Washington, DC.

Davis, E. E., K. Becker, and J. He (2004), Costa Rica Rift revisited: Constraints on shallow and deep hydrothermal circulation in young oceanic crust, Earth Planet. Sci. Lett., 222, 863-879, doi:10.1016/j. eps1.2004.03.032.

Doveton, J. H. (1994), Geological Log Analysis Using Computer Methods, Am. Assoc. Pet. Geol., Tulsa, Okla.

Fisher, A. T. (1998), Permeability within basaltic oceanic crust, Rev. Geophys., 36, 143-182, doi:10.1029/97RG02916.

Fisher, A. T., E. E. Davis, and K. Becker (2008), Borehole-to-borehole hydrologic response across $2.5 \mathrm{~km}$ in the upper oceanic crust: Implications for crustal-scale properties, J. Geophys. Res., 113, B07106, doi:10.1029/2007JB005447.

Gillis, K. M., and L. A. Coogan (2011), Secular variation in carbon uptake into the ocean crust, Earth Planet. Sci. Lett., 302, 385-392, doi:10.1016/ j.eps1.2010.12.030.

Goldberg, D., and A. L. Slagle (2009), A global assessment of deep-sea basalt sites for carbon sequestration, Energy Pro., 1, 3675-3682, doi:10.1016/j.egypro.2009.02.165.

Goldberg, D. S., T. Takahashi, and A. L. Slagle (2008), Carbon dioxide sequestration in deep-sea basalt, Proc. Natl. Acad. Sci. U. S. A., 105(29), 9920-9925, doi:10.1073/pnas.0804397105.

Guerin, G., D. S. Goldberg, and G. J. Iturrino (2008), Velocity and attenuation in young oceanic crust: New downhole log results from DSDP/ ODP/IODP Holes 504B and 1256D, Geochem. Geophys. Geosyst., 9, Q12014, doi:10.1029/2008GC002203.

House, K. Z., et al. (2006), Permanent carbon dioxide storage in deep-sea sediments, Proc. Natl. Acad. Sci. U. S. A., 103(33), 12,291-12,295, doi:10.1073/pnas.0605318103.

Jarrard, R. D., L. J. Abrams, R. Pockalny, R. L. Larson, and T. Hirono (2003), Physical properties of upper oceanic crust: Ocean Drilling Program Hole $801 \mathrm{C}$ and the waning of hydrothermal circulation, J. Geophys. Res., 108(B4), 2188, doi:10.1029/2001JB001727.

Kharaka, Y. K., et al. (2006), Gas-water-rock interactions in Frio Formation following $\mathrm{CO}_{2}$ injection: Implications for the storage of greenhouse gases in sedimentary basins, Geology, 34, 577-580, doi:10.1130/ G22357.1.

Le Quéré, C., et al. (2009), Trends in the sources and sinks of carbon dioxide, Nat. Geosci., 2, 831-836, doi:10.1038/ngeo689.

Matter, J. M., and P. B. Kelemen (2009), Permanent storage of carbon dioxide in geological reservoirs by mineral carbonation, Nat. Geosci., 2, 837-841, doi:10.1038/ngeo683.

Metz, B., et al. (2005), IPCC Special Report on Carbon Dioxide Capture and Storage, 442 pp., Cambridge Univ. Press, New York.

Oelkers, E. H., S. R. Gislason, and J. Matter (2008), Mineral carbonation of $\mathrm{CO}_{2}$, Elements, 4, 333-337, doi:10.2113/gselements.4.5.333.

Pezard, P. (1990), Electrical properties of mid-ocean ridge basalt and implications for the structure of the upper oceanic crust in Hole 504B, J. Geophys. Res., 95(B6), 9237-9264, doi:10.1029/JB095iB06p09237.

Shilobreeva, S., et al. (2011), Insights into C and H storage in the altered oceanic crust: Results from ODP/IODP Hole 1256D, Geochim. Cosmochim. Acta, 75, 2237-2255, doi:10.1016/j.gca.2010.11.027.

Staudigel, H., S. R. Hart, and S. H. Richardson (1981), Alteration of the oceanic crust: process and timing, Earth Planet. Sci. Lett., 52, 311-327, doi:10.1016/0012-821X(81)90186-2.

Takahashi, T., D. Goldberg, and J. C. Mutter (2000), Secure, long-term sequestration of $\mathrm{CO}_{2}$ in deep saline aquifers associated with oceanic and continental basaltic rocks, in Proceedings of the SRI International Symposium “Deep Sea \& $\mathrm{CO}_{2}$," pp. 1-7, The Ship Res. Inst., Mitaka, Japan.

Teagle, D. A. H., et al. (2006), Proc. Integr. Ocean Drill. Program, 309/ 312, Integ. Ocean Drill. Program, College Station, TX.

Tominaga, M., D. A. H. Teagle, J. C. Alt, and S. Umino (2009), Determination of the volcanostratigraphy of oceanic crust formed at superfast spreading ridge: Electrofacies analyses of ODP/IODP Hole 1256D, Geochem. Geophys. Geosyst., 10, Q01003, doi:10.1029/2008GC002143. Wilson, D., et al. (2003), Proceedings of the Ocean Drilling Program, Initial Reports, vol. 206, Ocean Drill. Program, College Station, Tex. Wilson, D. S., et al. (2006), Drilling to Gabbro in intact ocean crust, Science, 312, 1016-1020, doi:10.1126/science.1126090.

D. S. Goldberg and A. L. Slagle, Lamont-Doherty Earth Observatory, Earth Institute at Columbia University, 61 Rte. 9W, Palisades, NY 10964, USA. (aslagle@ldeo.columbia.edu) 